\title{
Do audit committee attributes improve integrated reporting quality? Evidence from European Companies listed on STOXX EUROPE 600 INDEX
}

saida belhouchet ( $\sim$ saidaolfa@gmail.com )

University of Sfax Faculty of Economics and Management of Sfax: Universite de Sfax Faculte des Sciences Economiques et de Gestion de Sfax https://orcid.org/0000-0002-6035-8691

Jamel CHOUAIBI

University of Sfax Faculty of Economics and Management of Sfax: Universite de Sfax Faculte des Sciences Economiques et de Gestion de Sfax

\section{Research Article}

Keywords: Audit committee attributes, The integrated reporting quality, STOXX EUROPE 600 INDEX

Posted Date: February 7th, 2022

DOI: https://doi.org/10.21203/rs.3.rs-1309211/v1

License: (c) (i) This work is licensed under a Creative Commons Attribution 4.0 International License. Read Full License 


\section{Abstract}

This paper aims to shed light on the relationship between audit committee attributes and the integrated reporting quality (IRQ). This study uses panel data and multiple regression. The outcomes almost entirely confirm the expectations relating to the impact of audit committee attributes on the IRQ. In particular financial expertise and meetings are shown to have a significant positive impact on IRQ. However, we do not find a significant association between key aspects of the audit committee function, such as audit committee independence and IRQ.

\section{Introduction}

Among the various mandatory and voluntary modes of corporate reporting, "integrated reporting (IR) has rapidly developed as a new accounting practice to help companies understand how they create value and be able to effectively communicate this to external stakeholders" (Perego et al., 2016). Thus, the audit committee is a topical subject because the spread of the practice of this committee is a relatively recent feature of the way in which boards of directors are organized. From an agency theory perspective, the audit committee, through its oversight, control, and monitoring functions, supports the stakeholders. Therefore, the contributions concerning the determinants of integrated reporting quality are limited. This significant gap in literature makes it necessary to analyze the key factors that can explain the quality of integrated reporting (Chouaibi et al., 2021).

The board of directors and its committees are a relevant corporate governance mechanism in monitoring managerial actions (Fama and Jensen, 1983). Therefore, an effective corporate governance structure would lead to greater value creation in organizations, while providing a basis for IR to provide quality information (Cooray et al., 2020). In recent years, both academics and standard setters have called for improvements in the audit committee configuration.

The economic theory that puts corporate governance issues into perspective is primarily agency theory. It considers that the agency relationship that exists between the principal (the shareholders) and the agent (the managers) involves asymmetries of information of two kinds: adverse selection and moral hazard. According to Gomez (1996), asymmetric information is at the origin of the contractual relationship. Thus, Audit committee is viewed as a monitoring tool to bridging the gap of information asymmetry which in turn results in minimizing agency costs (Altawalbeh, 2020).

The literature views the audit committee as a new institutional mechanism of corporate governance, set up as a final level of control over the quality of the audit process and reporting. Moreover, the originality of our research is justified by the scarcity of studies that have addressed the relationship between audit committee effectiveness and integrated reporting quality.

This is a subject that has gained momentum following the various financial scandals that have discredited the quality of the financial information published in the financial statements. In a climate where there is a loss of confidence in financial reporting, various regulatory texts have converged to redefine the governance bodies of the company, with the establishment of the audit committee within the board of directors. This body is now responsible for assisting the board in its responsibilities regarding the quality of financial information before its final approval and communication. In view of these considerations, we will ask the following question: Is the legal presence of the audit committee in listed European companies an effective control mechanism for improving the quality of integrated reporting?. 
This paper aims to fill the important gap by analyzing the effect of three audit committee attributes (independence, meeting frequency and financial expertise) on the IRQ, in regard to a selection of 213 European companies belonging to the STOXX EUROPE 600 index between 2008-2020.

In terms of contribution, the present study provides empirical evidence on the relationship between audit committee characteristics and the quality of integrated reporting released by European companies. Indeed, this paper may be useful for companies and stakeholders as it adds to the existing integrated reporting literature by analyzing the audit committee role in ensuring the consistency of integrated reporting, the external assurance of which is still an undiscovered research field. In the same vein, managers, shareholders, and politicians will be particularly interested in these findings. As a result, while determining the best reporting strategy (increasing risk estimation, stock volatility, and boosting long-term shareholder value and reputation), stakeholders should examine the accuracy of disclosure.

\section{Theoretical Background}

Our intention is to provide a detailed explanation of the related accounting phenomenon, the subject of our study, using the following three main theories: the agency theory, the signaling theory, and the resource dependency theory.

The agency theory. Is based on the existence of conflicts of interest between shareholders and managers, and different types of agency costs are associated with these conflicts (Jensen and Meckling, 1976). Indeed, it is based on the asymmetry of information that is at the origin of this conflict, as confirmed by Gomez (1996): "the asymmetry of information is therefore at the origin of the contractual relationship". The manager is perceived as opportunistic by his ability to use this information differential in his favor. The opportunism of the agents consists in concealing part of the information from the principal, in particular at the time of the signature of the contracts, which makes them incomplete, and therefore imperfect. It is the lack of transparency of information that allows the opportunism of managers and encourages them to manipulate the information according to their strategies. To this end, Gomez (1996) notes: "the opportunism of the actors involved is due to the asymmetries of information that they exploit".

This is why controls must be put in place in order to manage the flow of information as well as possible and to guarantee the convergence of interests between the stakeholders. Control mechanisms are analyzed according to an internal/external typology (Charreaux, 1997). From the perspective of agency theory, boards of directors act as internal control mechanisms that help align the interests of shareholders and those of managers (Fama and Jensen, 1983).

Signaling theory. Is based on the fact that information is unequally shared by the actors in a company and even if it were shared by all, the same information would not be perceived in the same way (Charreaux, 1997). The managers of a company thus have more information than investors. They make decisions that they consider favorable in order to convince the market; to do this, they use signals. A signal is a transfer of information to the actors in the firm in order to reduce the original information differentials, but its validity is subordinated to its cost (Spence, 1973). The emission of a signal is interpreted as additional information provided to the market with the aim of influencing investors and provoking the reaction of the share price (Noe and Rebello, 1996). Thus, a positive signal from a company's management can be used to anticipate better future performance and lead to an increase in the 
company's share price and vice versa. The managers of companies in a good financial situation have an interest in providing information to investors in order to distinguish themselves from firms in a bad position.

Resource dependency theory Developed by Pfeffer (1973) and Pfeffer and Salancik (1978), emphasizing the important role played by the board of directors in accessing resources that would enhance firm performance. The fundamental suggestion of resource dependence theory is the need for environmental links between the firm and the external resources needed to survive. This means that boards of directors are an important mechanism for absorbing critical elements of environmental uncertainty in the firm. Thus, environmental linkages could reduce the transaction costs associated with environmental interdependence. The organization's need to demand resources leads to the development of exchange relationships between organizations. In addition, the unequal distribution of resource requirements leads to interdependent organizational relationships. In summary, resource dependence theory provides a compelling rationale for creating linkages between the firm and its external environment through independent advice, as firms that create links could improve their survival and performance (Yusoff and Alhaji, 2012). Hence, the resource dependency theory suggests that larger audit committees are better able to provide greater resources and authority to effectively carry out their responsibilities (Allegrini and Greco, 2013).

\section{Hypotheses Development}

Because of the asymmetry of information between owners and managers, the board of directors plays a central role in safeguarding the interests of shareholders. Indeed, in order to minimize agency costs, the board assumes a supervisory role over the management through the approval of the company's strategy, the monitoring of the control system, and the maintenance of reliable accounting records. Given its various responsibilities, the board of directors generally delegates its oversight function to the audit committee. The audit committee can enhance the quality of the audit process by facilitating the disclosure of irregularities. One of the purposes of IR is to ensure transparency on financial and nonfinancial information, such as strategy, business models, risks and opportunities, governance, compensation, and sustainability. This increased transparency is likely to be used as a governance tool to prevent corporate opportunism.

Certain attributes of the audit committee make it more efficient to perform the above tasks in the disclosure process, leading to better information in the integrated reports. The unique assumptions regarding the effects of individual audit committee attributes on integrated reporting quality are elaborated below.

\section{Audit committee independence and integrated reporting quality}

One of the principal characteristics that can influence the audit committee's ability to supervise and monitor is its independence (Abbott et al., 2000; Bronson et al., 2009). Regulatory requirements, as well as academic requirements, emphasize the importance of this independence (King, 2009).

Li et al. (2012) noted that audit committee independence improves the credibility and quality of corporate financial and non-financial information. The ability of independent members to perform their oversight and control functions more effectively stems from the absence of relationships with internal management. For example, Zgarni et al. (2016) found that audit committee members' independence increases their involvement in ensuring the reliability of reported financials.

At the same time, Audit committee independence is expressed by the proportion of non-executive audit committee members, independence is thought to enhance the power of the audit committee in monitoring management 
behavior and improving the quality of financial reporting, including disclosure practices (Madi et al., 2014). Indeed, Duchin et al. (2010) suggested that a large number of independent audit committee members would improve the objectivity, reliability, and transparency of corporate financial reporting and voluntary disclosures. Taylor et al. (2011) reported a significant positive association between the existence of independent audit committee members and the level of voluntary corporate disclosure. In addition, Raimo et al. (2020) found that the independence of the audit committee allows an increase in the quality of the integrated reports provided by the company. On the other hand, Li et al. (2012); Ismail and Rahman (2011) could not find significant evidence on the association between audit committee independence and disclosure of Malaysian firms. Madi et al. (2014) add that audit committee size, independence, and multiple terms have a positive effect on integrated reporting quality. They also find that the frequency of meetings and financial expertise of the audit committee have no effect on the level of voluntary disclosure. Therefore, we introduce the following hypothesis:

\section{Hypothesis 1}

There is a positive association between the audit committee independence and integrated reporting quality.

\section{Audit committee financial expertise and integrated reporting quality}

The audit committee's competences and individual members' expertise, according to existing literature, improve its efficiency (Velte, 2018). The appropriate expertise of the members of the environmental audit committee is associated with greater transparency of environmental and sustainability-related information as this committee presents a guarantor of the quality of internal control and the reliability of environmental information (Jamoussi and Jarboui, 2018).

In the same vein, Huang and Thiruvadi (2008) show that there is a substantial link between audit committee accounting expertise and fraud prevention. On the contrary, Appuhami and Tashakor (2017) found no evidence of a link between audit committee accounting expertise and the level of corporate social responsibility disclosure; similarly, Madi et al. (2014) and Othman et al. (2014) found no significant link between audit committee members' financial expertise and voluntary disclosure. Similarly, Raimo et al. (2020) found that the educational background and experience in finance of the members of the audit committees have no effect on the quality of the integrated reports.

The findings of Cohen et al. (2013) indicate that combining industry expertise with accounting competence can increase the audit committee's efficiency in monitoring the financial reporting process. According to Sultana et al. (2015), audit committee members with financial expertise, prior audit committee experience, and independence are related with shorter audit delays. On the basis of these developments, we can make the following hypothesis:

\section{Hypothesis 2}

Audit committee expertise has a significant positive impact on integrated reporting quality.

\section{Audit committee meeting frequency and the integrated reporting quality}

According to Khlif and Samaha (2016), audit committee meetings improve internal control quality. In addition, Li et al. (2012) found that participating at least four audit committee meetings per year is significantly and positively connected to the level of voluntary disclosure. They argue that having audit committee meetings on a regular basis improves the committee's monitoring ability. Appuhami and Tashako (2017) investigated the link between audit 
committee size, frequency of meetings, committee independence, and gender diversity and voluntary corporate social responsibility disclosure. They found that audit committee size, frequency of meetings, committee independence, and gender diversity have a significant positive impact on the level of corporate social responsibility disclosure.

As previously noted, the IR's complexity requires extensive oversight and monitoring. In this regard, a higher frequency of audit committee meetings, as well as improved supervisory and monitoring functions for this body, could help to improve the quality of the process of acquiring and representing information in an integrated and quality manner. The rationale for including financial experts is to help other members understand the auditors' judgments and to discern the substance of disagreements between the external auditors and management (Mangena and Pike, 2012). Thus, audit committees that meet regularly, according to Karamanou and Vafeas (2005), have more time to efficiently perform the function of monitoring disclosure processes. In the same vein, Altawalbeh (2020) found that more audit committee meetings in a regular basis would enhance the effectiveness of the monitoring function ability to perform its monitoring function. Accordingly, the hypothesis to be empirically tested is:

\section{Hypothesis 3}

There is a positive association between audit committee meeting frequency and integrated reporting quality.

\section{Method}

\section{Sample construction and data collection}

Panel A of Table 1 provides an overview of the sample-selection process. The initial sample collected from the Thomson Reuters database consists of 6000 firm-year observations listed on the STOXX EUROPE 600 INDEX, covering the period from 2008-2020. From this initial sample, financial entities have been removed because their financial statements are incomparable with those of industrial firms. Additionally, all those firms for which it was impossible to collect all the necessary data for the research were also removed from the sample. Thus, the final unbalanced panel data sample is composed of 2769 firm-year observations.

In the sample, the following countries are represented: Austria, Belgaum, Finland, France, Germany, Ireland, Italie, Luxembourg, Netherlands, Portugal, Spain, United Kingdom, and Switzerland. Panel B of Table 1 shows that $29.7 \%$ of the sample's firms operate in the France, $24 \%$ in Germany, and $8.9 \%$ in Italy and Spain. The countries with the lowest representation are Portugal with $1.4 \%$ and Luxembourg, the UK, and the Switzerland with $0.9 \%$.

The firms in the sample operate in nine industries, which are provided in panel $\mathrm{C}$ of Table 1 . The economic sector classification by Thomson Reuters is used in this research to categorise the industries of the firms. The industries with the greatest representation are industrials, consumer discretionary, and health care, with $26.3,18.8$ and $12.20 \%$, respectively, and the lowest representation comes from telecommunications, with $5.7 \%$, and technology, with $2.8 \%$. 
Table 1

Sample selection and breakdown by country and industry

Panel A: Sample selection

Sample

Initial sample

Firms Observations

(-) Banks and financial institutions

(-) Other countries (Denmark, Norway, Poland and Sweden)

(-) Firms with missing data

Final sample

213

2769

Panel B: Sample distribution by country

Country

Firms \%

Austria

5

Belgaum

$5 \quad 0.023$

Finland

9

0.042

France

12

0.057

Germany

63

0.297

Ireland

51

0.240

Italy

6

19

0.028

Luxembourg

2

Netherlands

20

Portugal

3

Spain

19

0.089

UK

2

Switzerland

2

Total

213

0.009

Panel C: Sample distribution by industry

\begin{tabular}{|llll}
\hline ICB code & Industry & Firms & $\%$ \\
\hline 0001 & Consumer Discretionary & 40 & 0.188 \\
\hline 1000 & Technology & 6 & 0.028 \\
\hline 2000 & Energy & 15 & 0.070 \\
3000 & Health Care & 26 & 0.122
\end{tabular}

Note: Panel A describes the sample selection, Panel B provides the distributional properties of the full sample by country and Panel $\mathrm{C}$ presents sample distribution by industry. 


\begin{tabular}{|llll|}
\hline \multicolumn{2}{|l|}{ Panel A: Sample selection } & & \\
\hline 4000 & Industrials & 19 & 0.263 \\
\hline 5000 & Consumer Staples & 20 & 0.089 \\
\hline 6000 & Utilities & 19 & 0.094 \\
\hline 7000 & Basic Materials & 12 & 0.089 \\
\hline 9000 & Telecommunications & 213 & 1 \\
\hline Total & & & \\
\hline $\begin{array}{l}\text { Note: Panel A describes the sample selection, Panel B provides the distributional properties of the full sample by } \\
\text { country and Panel C presents sample distribution by industry. }\end{array}$ \\
\hline
\end{tabular}

\section{Measures}

\section{Dependent variable: Integrated reporting quality (IRQ)}

The dependent variable is the degree of consolidated integrated reporting which is calculated using the Thomson Reuters Datastream ASSET4. It represents the quality of the information contained within the integrated reports and will be measured by the ASSET4 Data Stream 'CGVS' item. CGVS is defined in Thomson Reuters' ASSET4 database as "the commitment and effectiveness of the company's management in creating an overall vision and strategy that integrates financial and non-financial aspects. It reflects a company's ability to convincingly demonstrate and communicate that it integrates economic (financial), social and environmental dimensions into its daily decisionmaking processes" (Thomson Reuters). This score takes values between 0 and 100 (Chouaibi et al., 2021).

\section{Independent variables}

Independent variables are defined as follows: audit committee independence (AC_IND) is measured by the percentage of independent members to the total number of the audit committee members (Raimo et al., 2020). In addition, we define the financial expertise of the audit committee (AC_EXP) as the proportion of audit committee members possessing professional accounting qualifications among the total number of audit committee members. Finally, the variable denoted (AC_MEET) is defined as the number of audit committee meetings held during the year.

\section{Board characteristics and firm's features as control variables}

The audit committee attributes are not the only factors that influence IRQ. We control for other determinants of IRQ that have been documented in prior studies and that might explain the effects of financial and economic peculiarities of the firms on the reporting quality. Thus, we retain as control variables: board independence, board diversity, CSR committee, leverage, Return on assets, Return on Equity and firm size. (B_IND) is measured as the proportion of independent directors to the total number of directors. (B_DIV) is measured as the proportion of female directors to the total number of directors. (CSRCOM) is a dummy variable that takes a score of 1 if there is a sustainability or CSR committee within the company and 0 otherwise. Leverage ratio (LEVE) is defined as the total debt divided by total assets. Return on assets (ROA) measured by net income divided by the total assets of firm $\mathrm{i}$ in time period ( $\mathrm{t}$ ). Return on Equity (ROE) is a measure of financial performance calculated by dividing net income by total equity. Firm size (FSIZE) is defined as the natural logarithm of total assets. 
To control for possible variable across countries, industries and time, we also include country, industry and year dummies (the industry dummies are based on the first digit of the SIC code). The specific measures of all variables are described in Table 2.

Table 2

Variable's description

\begin{tabular}{|c|c|c|c|}
\hline $\begin{array}{l}\text { Variable } \\
\text { type }\end{array}$ & $\begin{array}{l}\text { Variable's } \\
\text { name }\end{array}$ & Symbol & Definitions \\
\hline \multirow{6}{*}{$\begin{array}{l}\text { Dependent } \\
\text { variable } \\
\text { Independent } \\
\text { Variables }\end{array}$} & $\begin{array}{l}\text { Integrated } \\
\text { Reporting }\end{array}$ & IRQ & $\begin{array}{l}\text { It is a score "CGVS" that consists of a series of items that count } \\
\text { the company's performance in ethics developed by ASSET } 4 \text {. }\end{array}$ \\
\hline & Quality & & \\
\hline & & & \\
\hline & $\begin{array}{l}\text { Audit } \\
\text { committee } \\
\text { independence }\end{array}$ & AC_IND & $\begin{array}{l}\text { The percentage of independent members to the total number of } \\
\text { the audit committee members. }\end{array}$ \\
\hline & $\begin{array}{l}\text { Audit } \\
\text { committee } \\
\text { financial } \\
\text { expertise }\end{array}$ & AC_EXP & $\begin{array}{l}\text { The proportion of audit committee members possessing } \\
\text { professional accounting qualifications among the total number } \\
\text { of audit committee members. }\end{array}$ \\
\hline & $\begin{array}{l}\text { Audit } \\
\text { committee } \\
\text { meeting } \\
\text { frequency }\end{array}$ & AC_MEET & $\begin{array}{l}\text { Is defined as the number of audit committee meetings held } \\
\text { during the year. }\end{array}$ \\
\hline \multirow[t]{7}{*}{$\begin{array}{l}\text { Control } \\
\text { variables }\end{array}$} & $\begin{array}{l}\text { Board } \\
\text { Independence }\end{array}$ & B_IND & $\begin{array}{l}\text { The proportion of independent directors to the total number of } \\
\text { directors. }\end{array}$ \\
\hline & Board Diversity & B_DIV & $\begin{array}{l}\text { The proportion of independent directors to the total number of } \\
\text { directors. }\end{array}$ \\
\hline & $\begin{array}{l}\text { CSR } \\
\text { Committee }\end{array}$ & CSRCOM & $\begin{array}{l}\text { Is a dummy variable that takes a score of } 1 \text { if there is a } \\
\text { sustainability or CSR committee within the company and } 0 \\
\text { otherwise. }\end{array}$ \\
\hline & Leverage & LEVE & The total debt divided by total assets. \\
\hline & $\begin{array}{l}\text { Return On } \\
\text { Assets }\end{array}$ & ROA & Total income to its total asset. \\
\hline & $\begin{array}{l}\text { Return On } \\
\text { Equity }\end{array}$ & ROE & Net income to total shareholders' equity. \\
\hline & Firm Size & FSIZE & The natural logarithm of total assets. \\
\hline
\end{tabular}

\section{Regression Model}

To test the three hypotheses described in Section 2, we estimate a panel regression model where the integrated reporting quality is used as a dependent variable.

We have specified one econometric model for estimation. Equation (1) summarize the panel data model: 


$$
\begin{gathered}
I R Q_{i, t}=\beta_{0}+\beta_{1} A C_{-} I N D_{i, t}+\beta_{2} A C_{-} E X P_{i, t}+\beta_{3} A C C_{-} \operatorname{MEET}_{i, t}+ \\
\beta_{4} B_{-} I N D_{i, t}+\beta_{5} B_{-} D I V_{i, t}+\beta_{6} C S R C O M_{i, t}+\beta 7 L E V E_{i, t}+\beta_{8} R O A_{i, t}+\beta 9 R O E_{i, t}+ \\
\beta_{10 F S I Z E_{i, t}}+\beta_{k} \sum_{12}^{25} Y E A R_{i, t}+\beta_{j} \sum_{26}^{39} \operatorname{COUNTRY}+\beta_{z} \sum_{40}^{49} I N D U S T R Y_{i, t}+\varepsilon_{i, t}(1)
\end{gathered}
$$

Where:

IRQ: integrated reporting quality; AC_IND: audit committee independence; AC_EXP: audit committee financial expertise; AC_MEET: audit committee meeting frequency; B_IND: board independence ; B_DIV: board diversity ; CSRCOM: corporate social responsibility committee; LEVE : the firm's leverage ratio; ROA: return on assets; ROE: return on equity ; FSIZE: firm size.

YEAR, INDUSTRY and COUNTRY stand respectively for year, industry and country effects; $\varepsilon_{i \mathrm{ti}}$ is the random error term.

Concerning the indices $\mathrm{i}$ and $\mathrm{t}$, they correspond to firm and period components of the study. Detailed definitions and measurements of all study variables are summarized in Table 2.

Equations are estimated using a panel data methodology, applying the ordinary least squares regression (GLS).

\section{Results}

\section{Descriptive statistics}

Table 3 reports some descriptive statistics for all the analyzed variables, except the industry and year dummies used in the model analysis. All the non-indicator variables are winterized at the $1 \%$ and $99 \%$ levels to eliminate extreme observations.

Table 3 presents both continuous and binary variables related to descriptive statistics in Panels A and B. Panel A illustrates the continuous variables' mean standard deviation, minimum, and maximum values. Panel $B$ displays the mean, standard deviation, as well as the minimum and maximum values for binary variables. We can see that companies are on average a fairly high quality among the analyzed reports. Descriptive analysis suggests that the mean from IRQ is 0.886 . The results are consistent with Raimo et al. (2020). The high level of quality of integrated reporting makes it very easy for business stakeholders to determine the future performance of the business.

The descriptive statistics show that the average percentage of nonexecutive members within the audit committee is around 0.7712 and $66 \%$ have at least one member with an educational background and experience in finance. In addition, on average, the audit committees of the companies analysed meet about 8 times per year.

As regard to control variables, the descriptive statistics show that on average, the boards of directors have a high degree of independence (0.6041). Furthermore, the selected companies have, on average, a percentage of female directors equal to about $26 \%$. The average value of the Corporate Social Responsibility Committee is a $72.1 \%$. Regarding the debt ratio, the companies in question have an average ratio of around $29.1 \%$, it is important to note that European companies are more indebted. In terms of firm profitability (ROA), the mean of the firm profitability is 0.054, while the maximum and minimum are 0.693 and-1.209, respectively, with a standard deviation of 0.075 . 
In addition, the companies in the sample have an average ROE of 0.117 . We note that, on average, size of the companies (measured by total log assets) of around 16 with a low of 4.468 and a high of 19.745 . This shows that the firms in our sample are large sizes.

Table 3

Descriptive statistics

\begin{tabular}{|c|c|c|c|c|c|}
\hline Variables & Obs & Mean & SD & Minimum & Maximum \\
\hline \multicolumn{6}{|c|}{ Panel A: continuous variables } \\
\hline IRQ & 2769 & 0.886 & 0.223 & 0.013 & 1 \\
\hline AC_IND & 2769 & 0.7712 & 0.2393 & 0 & 1 \\
\hline AC_MEET & 2769 & 8.065 & 3.541 & 6 & 94.5 \\
\hline B_IND & 2769 & 0.6041 & 0.2490 & 0 & 1 \\
\hline B_DIV & 2769 & 0.2622 & 0.1445 & 0 & 1 \\
\hline LEVE & 2769 & 0.291 & 0.167 & 0.012 & 0.96 \\
\hline ROA & 2769 & 0.054 & 0.075 & -1.209 & 0.693 \\
\hline ROE & 2769 & 0.117 & 0.206 & -3.345 & 2.659 \\
\hline FSIZE & 2769 & 15.966 & 1.837 & -4.468 & 19.745 \\
\hline \multicolumn{3}{|c|}{ Panel B: Binary variables } & \multicolumn{2}{|c|}{ Modalities\% } & \\
\hline \multirow[t]{2}{*}{ AC_EXP } & & & \multicolumn{2}{|l|}{1} & 0.664 \\
\hline & & & \multicolumn{2}{|l|}{0} & 0.336 \\
\hline \multirow[t]{2}{*}{ CSRCOM } & & & \multicolumn{2}{|l|}{1} & 0.721 \\
\hline & & & \multicolumn{2}{|l|}{0} & 0.279 \\
\hline
\end{tabular}

\section{Correlation analysis}

We explore the relationship between the characteristics of the audit committee and integrated reporting quality through a Pearson rank correlation. The Table 4 shows the results. They show no evidence of an unacceptable level of multicollinearity. In fact, the highest correlation coefficient is 0.66 for ROE and ROA. According to Farrar and Glauber (1967), harmful levels of multicollinearity should not exist until the correlation coefficient reaches \pm 0.8 or \pm 0.9 . In support of this, we have evaluated the potential multicollinearity among the variables also using a variance inflator factor (VIF) analysis. VIFs vary between a low value of 1.01 to a high value of 1.83 . The effect of multicollinearity is not significant if all VIFs are less than 10 (Myers, 1990). Therefore, multicollinearity does not represent a problem in the interpretation of our findings 
Table 4

Pearson correlation matrix and VIF

\begin{tabular}{|llllllllllll} 
Variables & $(1)$ & $(2)$ & $(3)$ & $(4)$ & $(5)$ & $(6)$ & $(7)$ & $(8)$ & $(9)$ & (10) & VIF
\end{tabular}

AC_IND (1) 1

1.14

AC_EXP (2) $\quad 0.049 \quad 1$

$\begin{array}{llll}\text { AC_MEET } & 0.036 & -0.017 & 1\end{array}$

1.07

(3)

B_IND (4) $\quad 0.321 \quad-0.011 \quad 0.040$

$\begin{array}{llllll}\text { B_DIV (5) } \quad-0.018 & -0.045 & 0.031 & 0.106 & 1\end{array}$

$\begin{array}{llllll}\operatorname{CSRCOM}(6) & -0.019 & 0.209 & -0.004 & -0.025 & 0.040\end{array}$

\begin{tabular}{llllllllllll|} 
LEVE (7) & 0.001 & 0.028 & 0.034 & -0.016 & -0.0104 & -0.001 & 1 & & & 1.04 \\
ROA (8) & -0.019 & -0.027 & -0.009 & 0.028 & 0.003 & -0.032 & -0.096 & 1 & & 1.83 \\
ROE (9) & -0.045 & -0.014 & -0.006 & 0.037 & -0.018 & 0.018 & -0.042 & 0.66 & 1 & 1.79 \\
\hline FSIZE (10) & 0.071 & 0.167 & 0.060 & 0.030 & -0.022 & 0.239 & 0.128 & 0.03 & 0.04 & 1 & 1.12
\end{tabular}

Note: This table presents the correlation matrix between the variables used in the study. Variables are defined in

\section{Fixed or Random Effect}

Given the particular nature of panel data, it is necessary to follow the order of some econometric steps and perform certain tests to lead to robust estimations. First, we point out that the fixed effects model is discarded since our regression includes time-invariant dummy variables. Performing a fixed-effect regression would lead to arbitrarily omitting such variables. The Breusch-Pagan LM test for randomness produces a significant Chi-square value. We confirm the existence of individual effects, and we run a random effect regression model. Second, we test for panel level heteroskedasticity using the Breusch-Pagan test, as shown in Table 5. According to this table, the tests applied allowed acceptance of the null hypothesis of heteroscedasticity ( $p$-value $=0.7347$ ).

The decision of fixed and random effects rests on the result of Hausman's test. A Hausman test has been typically used to determine the consistency of the GLS estimator in static models with pooled cross-section-time-series data. This test, when run for the data of the present study, gave a significant result, which proves the use of random effect regression analysis for us model before regression analysis. Hausman's test was run, and for our model, a random effect was applied as per the results of Hausman's test.

\section{Test of Hypotheses}

Table 5 presents the results of an estimating model where IRQ is the dependent variable. As shown by this table, a regression model is used to test the link between the audit committee attributes and the IRQ. 
The results support $\mathrm{H} 2$ and $\mathrm{H} 3$, while $\mathrm{H} 1$ is not supported. In particular, the results for $\mathrm{H} 1$ the results show a positive but non-significant relationship between AC_IND and IRQ at $p=0.318$. This result suggests that greater independence of the audit committee has no significant impact on integrated reporting quality. Thus, $\mathrm{H} 1$ is rejected. The results obtained regarding the impact of the audit committee independence on the IRQ extend those obtained by Li et al. (2012) and Ismail and Rahman (2011).

In addition, the results show that the educational background and experience in finance of the audit committee members do influence the quality of the integrated reports provided by the firms $(p=0.03)$. Therefore, $\mathrm{H} 2$ is accepted. This result supports various studies (for instance: Raimo et al. (2020) and Velte, 2018). In which there is a positive and significant association between audit committee financial expertise and integrated reporting quality.

Finally, the results for $\mathrm{H} 3$ show a positive and significant relationship between AC_MEET and IRQ at $p=.099$. This result suggests that a greater number of annual meetings by audit committees would favour the dissemination of higher-quality integrated reports. The results obtained regarding the impact of the audit committee meeting on the IRQ extend those obtained by Altawalbeh (2020) and Raimo et al. (2020).

With regard to the control variables, the results show a positive effect of board characteristics. In this regard, they highlight the positive influence BIND and BDIV on the IRQ at $p=0.052, p=.04$, respectively. Thus, we confirm Raimo et al. (2020) arguments' that the presence of a greater number of nonexecutive members on the board of directors favours the publication of higher quality integrated reports. In addition, Appuhami and Tashakor (2017) analysed Australian firms and underlined the positive effect of some audit committee characteristics such as size, independence, frequency of meetings and gender diversity on the level of CSR disclosure. They also stress that the presence of a CSR or sustainability committee has a positive effect on the quality of integrated reports. They show a positive effect of CSRCOM on the IRQ at $p=.096$. Also, we find that LEVE, ROA and ROE are non-significant associated with integrated reporting quality. Finally, Table 5 shows a positive effect of firm size, with FSIZE having a positive effect on the IRQ at $p=.015$ 
Table 5

Regression results

\begin{tabular}{|c|c|c|}
\hline Variables & Coef. & $P>Z$ \\
\hline AC_IND & 0.18 & 0.318 \\
\hline AC_EXP & $0.7348^{\star *}$ & 0.03 \\
\hline AC_MEET & $0.244^{*}$ & 0.099 \\
\hline B_IND & $0.008^{\star *}$ & 0.052 \\
\hline B_DIV & $0.020^{\star \star}$ & 0.04 \\
\hline CSRCOM & $0.4091 * \star$ & 0.096 \\
\hline LEVE & -4.093 & 0.158 \\
\hline ROA & -7.728 & 0.216 \\
\hline ROE & 2.949 & 0.147 \\
\hline FSIZE & $0.736^{\star \star}$ & 0.015 \\
\hline Intercept & $75.573^{\star \star \star}$ & 0 \\
\hline Year fixed effect & Included & Included \\
\hline Industry fixed effect & Included & Included \\
\hline Country fixed effect & Included & Included \\
\hline Nb. Of Obs. & 2769 & \\
\hline $\mathrm{R}^{2}$ & 0.16 & \\
\hline Homogeneity test & $6.56^{* * \star}$ & \\
\hline Hausman test & 7.41 (p-valu & $e=0.7647)$ \\
\hline Breusch-Pagan test for Heteroskedasticity & $0.11(p-v a l u$ & $e=0.7347)$ \\
\hline
\end{tabular}

\section{Note}

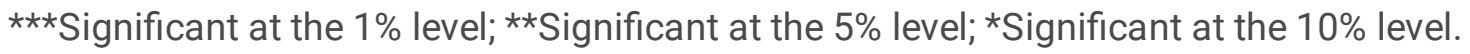

\section{Robustness Tests}

We ran a robustness test to ensure that the results were consistent. We control for the legal system of the country by including the variable CIVLAW to see what influence the country's legal tradition may have on the sampled companies and the integrated reporting quality. If the company operates in a civil law country, this variable has a value of 1 ; otherwise, it has a value of 0 . In terms of the implementation of this reporting tool, this strategy is similar to that taken by Fras Aceituno et al. (2013). As a result, the new model of analysis that we propose is reflected in the following equation: 


$$
\begin{aligned}
& I R Q_{i, t}=\beta_{0}+\beta_{1} A C_{-} I N D_{i, t}+\beta_{2} A C_{-} E X P_{i, t}+\beta_{3} A C_{-} M E E T_{i, t}+ \\
& \beta_{4} B_{-} I N D_{i, t}+\beta_{5} B_{-} D I V_{i, t}+\beta_{6} \operatorname{CSRCOM}_{i, t}+\beta_{7} L E V E_{i, t}+\beta_{8} R O A_{i, t}+\beta_{9} R O E_{i, t}+ \\
& \beta_{10} \text { SSIZE }_{i, t}+\beta_{11 C I V L A W}+\beta_{\mathrm{k}} \sum_{13}^{26} Y E A R_{i, t}+\beta_{j} \sum_{27}^{40} \operatorname{COUNTRY}+\beta z \sum_{41}^{50} \operatorname{INDUSTRY}_{i, t}+\varepsilon_{i, t}(2)
\end{aligned}
$$

These tests achieved results are displayed in Table 6.

\begin{tabular}{|c|c|c|}
\hline Variables & Coef. & $P>Z$ \\
\hline AC_IND & 0.18 & 0.318 \\
\hline AC_EXP & $0.7348^{\star *}$ & 0.03 \\
\hline AC_MEET & $0.244^{\star}$ & 0.099 \\
\hline B_IND & $0.008^{\star \star}$ & 0.052 \\
\hline B_DIV & 0.020 ** & 0.04 \\
\hline CSRCOM & $0.4091^{\star \star}$ & 0.096 \\
\hline LEVE & -4.093 & 0.158 \\
\hline ROA & -7.728 & 0.216 \\
\hline ROE & 2.949 & 0.147 \\
\hline FSIZE & 0.736 ** & 0.015 \\
\hline CIVLAW & 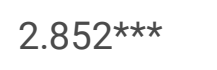 & 0.002 \\
\hline Intercept & $75.573^{* \star *}$ & 0 \\
\hline Year fixed effect & Included & Included \\
\hline Industry fixed effect & Included & Included \\
\hline Country fixed effect & Included & Included \\
\hline Nb. Of Obs. & 2769 & \\
\hline $\mathrm{R}^{2}$ & 0.168 & \\
\hline Homogeneity test & 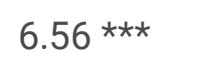 & \\
\hline Hausman test & 7.41 (p-valu & $=0.7647)$ \\
\hline Breusch-Pagan test for Heteroskedasticity & 0.11 (p-valu & $=0.7347)$ \\
\hline
\end{tabular}

Table 6

Robustness analysis 


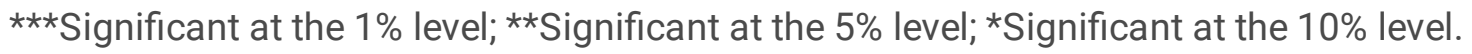

The findings show that the legal traditions of the country in which the company operates have no effect on the influence of audit committee features on integrated reporting quality. The findings also demonstrate that the civil law system (CIVLAW) has a positive and significant impact on integrated reporting quality (IRQ) at $p=0.002$. This indicates how companies operating in countries with civil law provide higher-quality integrated reports than companies operating in countries with different legal systems.

\section{Theoretical Contribution}

The application of the agency, signaling, and resource dependency development theories in the framework of this research shows that a director's application of ethical behavior is more likely to enhance the accuracy of nonfinancial information at the cultural, environmental, and social levels, while reinforcing, encouraging, and consolidating the definition of CSR within companies. The findings provide contradictory evidence from the agency theory perspective, carefully handling these corporate governance characteristics is essential in order to strike a balance between principal agent relationships and avoid future agency costs. Also, the paper contributes to addressing the gap that currently exists as to what is meant by IRQ. Despite the large number of studies that examine IR, there is still a lack of consensus on understanding IRQ.

\section{Practical Implications}

Several practical implications. In fact, managers and policymakers can benefit from our findings as well. In terms of managers, our findings show that financial accounting knowledge on the audit committee enhances the external auditors' dependence on internal audit work, which improves integrated reporting quality. In terms of policymakers, our findings show that having financial specialists on an audit committee has a major impact on improving financial reporting quality through timely disclosure.

The findings of this paper have significant policy consequences. Through proper legislation, policymakers should encourage the formation of larger audit committees and audit committees with a higher percentage of independent members. They should also establish a minimum number of audit committee meetings per year. These regulations, which aim to increase the efficacy of audit committees' supervisory and monitoring tasks, would promote corporate transparency and improve the quality of integrated reports.

\section{Future Research Directions}

This study offers some significant findings, they should be considered with care due to the study's limitations. To start, only three audit committee attributes that were relevant to the study topic were chosen for this investigation. As a result, future research into additional audit committee characteristics, such as audit committee tenure, is possible. Second, the study sample included non-financial industries, which have a variety of audit committee and reporting processes. As a result, financial organizations are excluded from all studies on the impact of audit committee attributes on integrated reporting quality. It will be interesting to see if there is a major difference between financial and non-financial organizations when it comes to the impact of audit committee attributes on integrated reporting quality. Third, the absence of endogeneity tests, i.e., the relationship between audit committee attributes and the integrated reporting quality, could be studied in both directions. 


\section{Conclusion}

This paper was designed to investigate the impact of audit committee attributes on the integrated reporting quality of European companies belonging to the STOXX EUROPE 600 index. For a more reliable estimation of integrated reporting quality, the measures proposed by ASSET4 were used. This paper attempts to fill the gap in the literature by theoretically and empirically investigating the role of audit committee characteristics.

This study tested the effects of audit committee independence, audit committee financial expertise, and audit committee meeting frequency as determinants of integrated reporting quality. The analysis was conducted on a sample of 213 European companies belonging to the STOXX EUROPE 600 index for the period 2008-2020. We find that the educational background and experience in finance, and the annual activity level of the audit committee were shown to have à positive effect on the IRQ. On the contrary, this study highlighted that the percentage of independent members of the audit committee does not affect the IRQ.

\section{Declarations}

Conflict of interest : There are no potential conflicts of interest for the authors to disclose. There is no financial interest to report, and all authors have seen and agree with the contents of the text. We certify that the submission is unique and that it is not currently under consideration by another publisher.

\section{References}

1. Abbott, L. J., Y. Park, and S. Parker. 2000. The effects of audit committee activity and independence on corporate fraud. Managerial Finance 26 (11): 55-68.

2. Allegrini, M. and G.Greco. 2013. Corporate boards, audit committees and voluntary disclosure: Evidence from Italian listed companies. Journal of Management and Governance 17 (1): 187-216.

3. Altawalbeh, M. A. F. 2020. Audit Committee Attributes, Corporate Governance and Voluntary Disclosure: Evidence from Jordan. International Journal of Academic Research in Accounting, Finance and Management Sciences 10 (2): 233-243.

4. Appuhami, R., and S. Tashakor. 2017. The impact of audit committee characteristics on CSR disclosure: An analysis of Australian firms. Australian Accounting Review 27 (4): 400.

5. Bronson, S. N., J. V. Carcello, C. W. Hollingsworth, and T. L. Neal. 2009. Are fully independent audit committees really necessary? Journal of Accounting and Public Policy 28 (4): 265-280.

6. Charreaux, G. 1997. Le gouvernement des entreprises, Paris. Economica.

7. Chouaibi, J., S. Belhouchet, R. Almallah, and Y. Chouaibi. 2021. Do board directors and good corporate governance improve integrated reporting quality? The moderating effect of CSR: an empirical analysis. EuroMed Journal of Business, Vol. ahead-of-print No. ahead-of-print. https://doi.org/10.1108/EMJB-04-20210066.

8. Cohen, J., U. Hoitash, and G. Krishnamoorthy, and A.Wright. 2014. The effect of audit committee industry expertise on monitoring the financial reporting process. The Accounting Review 89 (1): 243-273.

9. Cooray, T., A. D. Gunarathne, and S. Senaratne. 2020. Does corporate governance affect the quality of integrated reporting? Sustainability 12 (10): 4262. 
10. Duchin, R., J. G. Matsusaka, and O. Ozbas. 2010. When are outside directors effective? Journal of financial economics 96 (2): 195-214.

11. Fama, E. F., and M. C. Jensen. 1983. Separation of ownership and control. The Journal of Law and Economics 26 (2): 301-325.

12. Farrar, D. E., and R. R. Glauber. 1967. Multicollinearity in regression analysis: The problem revisited. The Review of Economic and Statistics 49: 92-107. https://doi.org/10.2307/1937887.

13. Frias-Aceituno, J. V., L. Rodriguez-Ariza, and I. M. Garcia-Sanchez. 2013. The role of the board in the dissemination of integrated corporate social reporting. Corporate Social Responsibility and Environmental Management 20 (4): 219-233.

14. Gomez, P. Y. 1996. Le gouvernement de l'entreprise, Modèles économiques de l'entreprise et pratiques de gestion ", InterEditions.

15. Huang, H., and S. Thiruvadi. 2009. Audit committee characteristics and corporate fraud. International Journal of Public Information Systems: 71-82.

16. IIRC. 2013. International <IR> framework. Retrieved from: http://integratedreporting.org/resource/internationalir-framework.

17. Ismail, K. N. I. K., and S. A. S. Abd Rahman. 2011. Audit committee and the amendments of quarterly financial reports among Malaysian companies. Jurnal Pengurusan (UKM Journal of Management 32.

18. Jamoussi, M. M., and A. Jarboui. 2018. L'audit environnemental, la gouvernance et la divulgation volontaire de l'information environnementale: Cas des entreprises françaises. Accountability, Responsabilités et Comptabilités, Poitier, France. pp.cd-rom. ffhal-01907555ff.

19. Jensen, M. C., and W. H. Meckling. 1976. Theory of the firm: Managerial behavior, agency costs, and ownership structure. Journal of Financial Economics 3 (4): 305-360.

20. Karamanou, I., and N. Vafeas. 2005. The association between corporate boards, audit committees, and management earnings forecasts: An empirical analysis. Journal of Accounting research 43 (3): 453-486.

21. Khlif, H., and K. Samaha. 2014. Internal control quality, Egyptian standards on auditing, and external audit delays: Evidence from the Egyptian stock exchange. International Journal of Auditing 18 (2): 139-154.

22. King, I. I. I. 2009. King report on governance for South Africa. Retrieved from: https://cdn.ymaws.com/www.iodsa.co.za/resource/resmgr/king_iii/King_Report_on_Governance_fo.pdf.

23. Li, J., M. Mangena, and R. Pike. 2012. The effect of audit committee characteristics on intellectual capital disclosure. The British Accounting Review 44 (2): 98-110.

24. Madi, H., Z. Ishak, and N. A. A. Manaf. 2014. The impact of audit committee characteristics on corporate voluntary disclosure 164: 486-492.

25. Mangena, M., and R. Pike. 2005. The effect of audit committee shareholding, financial expertise and size on interim financial disclosures. Accounting and Business Research 35 (4): 327-349.

26. Myers, R. H. 1990. Classical and modern regression with applications (Second ed.). Belmont, CA: Duxbury Press.

27. Noe, T. H., and M. J. Rebello. 1996. Asymmetric Information, managerial Opportunism, Financing, and payout Policies. Journal of Finance 51 (2): 637-666.

28. Othman, R., I. F. Ishak, S. M. M. Arif, and N. A. Aris. 2014. Influence of audit committee characteristics on voluntary ethics disclosure. Procedia-Social and Behavioral Sciences 145: 330-342. 
29. Perego, P., S. Kennedy, and G. Whiteman. 2016. A lot of icing but little cake? Taking integrated reporting forward. J. Clean. Prod 136: 3-64.

30. Pfeffer, J. 1973. Size, composition and function of hospital boards of directors: a study of organizationenvironment linkage. Adm. Sci. Q18 (3): 349-364.

31. Pfeffer, J., and G. R. Salancik. 1978. The external control oforganizations: A resource dependence perspective. New York. Harper et Row.

32. Raimo, N., F. Vitolla, A. Marrone, and M. Rubino. 2020. Do audit committee attributes influence integrated reporting quality? An agency theory viewpoint. Bus Strat Env:1-13. https://doi.org/10.1002/bse.2635.

33. Spence, M. 1973. Job Market Signaling. Quarterly Journal of Economics 87,August: 335-374.

34. Sultana, N., H. Singh, and J.-L. W. M. Van der, and Zahn. 2015. Audit committee characteristics and audit report lag. International Journal of Auditing 19 (2): 72-87.

35. Taylor, D., and J. X. Zhang. 2011. Corporate risk disclosures: the influence of institutional shareholders and the audit committee. Journal of Corporate Finance 9 (1): 1-27.

36. Velte, P. 2018. Is audit committee expertise connected with increased readability of integrated reports: Evidence from EU companies. Problems and Perspectives in Management 16 (2): 23-41.

37. Yusoff, W. F. W., and I. A. Alhaji. 2012. Insight of corporate governance theories. Journal of Business and Management 1 (1): 52-63.

38. Zgarni, I., K. Hlioui, and F. Zehri. 2016. Effective audit committee, audit quality and earnings management: Evidence from Tunisia. Journal of Accounting in Emerging Economies 6 (2): 138-155. 